\title{
Risks of a slow-motion EMU reform
}

\author{
László Andor \\ Corvinus University of Budapest, Hungary
}

The article provides a critical assessment of how the Economic and Monetary Union was designed, implemented and reformed in the European Union and discusses the risks of a slow-motion reform process. It is argued that the fact that the euro area economy has recovered in the last few years has become a source of complacency and delays. In particular, powerful forces continue to downplay the importance of systemic reconstruction and the risk of disintegration remains high despite the relative tranquillity of markets in the 2014-2018 period. Finally, the article evaluates competing paradigms about the eurozone crisis and the pros and cons of fiscal capacity building.

Keywords: European Union, Great Recession, eurozone crisis, divergence, EMU reform, fiscal capacity

JEL codes: $E 63, F 45$

\section{INTRODUCTION}

The 20th birthday of the European single currency is a time for celebration, but even more for a critical assessment of how the Economic and Monetary Union (EMU) was designed, implemented and reformed in the European Union (EU). The past ten years and especially the acute crisis of the 2010-2014 period exposed a number of weaknesses, the so-called design flaws in the system. The euro area came close to disintegration in 2011-2012, when a reform process began. However, the speed and manner of EMU reform must themselves be the subject of serious criticism. The fact that the euro area economy has recovered in the last few years has become a source of complacency and delays. EMU reform has been taking place in slow motion. While the European Commission has responded to the call for a eurozone fiscal capacity with modest and controversial proposals, powerful forces continue to downplay the importance of systemic reconstruction. Since, however, the political capital to muddle through another crisis with austerity policies is now lacking, the risk of disintegration remains high despite the relative tranquillity of markets in the 2014-2018 period. In order to stimulate a more dynamic debate, the divisive nature of a minimalist EMU will be explained here, together with the competing paradigms about the eurozone crisis and the pros and cons of fiscal capacity building.

\section{TEN YEARS, TEN MOMENTS}

One way to describe the weaknesses of the EMU is that it is a system that was built for 'fair weather', but its architecture has been lacking the components that would have made it crisisproof. Indeed, official evaluations ${ }^{1}$ of the first ten years in 2008 were highlighting the

1. See most of all the 7 May 2018 Commisson press release under the title ' 10 years of Economic and Monetary Union: a resounding success but testing times ahead' (http://europa.eu/rapid/pressrelease_IP-08-716_en.htm). 
smooth experience of the pre-crisis period. However, the collapse of Lehman Brothers in September 2008 brought abrupt 'climate change' into international finance, and this sudden stop also triggered an unprecedented recession across Europe. The 15th of September 2008 stands out as a most critical date in recent economic history. From a European perspective, we can highlight nine others to recall the crisis dynamics but also some of the lessons learned from this decade.

Shortly after the fall of Lehman Brothers, some non-eurozone EU member states asked for International Monetary Fund (IMF) support. The Hungarian loan (6 November 2008) was orchestrated with extraordinary speed. This gave an impression that non-eurozone countries might be more vulnerable than those inside the euro area, but also that we can all rely on the IMF, which quickly reactivated itself after a few years of retreat. Remembering the 2008 Hungarian bail-out also invites thinking about the potential political consequences of sovereign debt crisis and excessive austerity.

As Europe went through the most severe post-war recession in 2009, fiscal and monetary expansion was implemented, but some of the smaller and more peripheral member states found themselves in a debt trap. Being cut off from the markets, Greece was the first to ask for official support. The day of the first Greek bail-out (9 May 2010) stands out, since it was also the day on which the so-called Troika ${ }^{2}$ was launched, and an ad hoc instrument called the European Financial Stabilisation Mechanism (EFSM) was established.

Avoiding sovereign default was a priority in the early crisis response, both outside and inside the euro area. Shortly after, however, leaders started to reconsider. At Deauville (19 October 2010), Angela Merkel and Nicolas Sarkozy opined that the private sector also has to participate in absorbing losses. This was the right idea expressed at the wrong time and in the wrong way, causing damage directly to Greece but also ensuring that the domino would hit further countries of the euro area periphery.

One year later, it was not only small and medium-sized countries like Greece, Ireland and Portugal, but also Spain and Italy that came under the pressure of the financial markets. In Rome, just like in Greece at the same time, a technocratic government was formed, which started its work with a major overhaul of the pension system (6 December 2011). The tearful request for sacrifice raised the question of whether the functioning of the EMU can be reconciled with maintaining the welfare state, at least on the periphery of the euro area.

The year 2012 brought about a paradigm change and 26 July stands out as a most important date, when Mario Draghi in London announced he would do whatever it takes to save the euro. Under the given conditions, breaking the self-imposed constraints of the European Central Bank (ECB) became the real game-changer. It was not the austerity measures within specific countries, but the ECB's action as a quasi lender of last resort which started to restore confidence in the system. Draghi's semi-improvised announcement came just one month after the European Council failed to address the plight of crisis countries like Italy and Spain. Nevertheless, the European Council launched the work on a report that outlined the vision of EMU reform.

While investor sentiment turned around in 2012, the agreement to bail out Cyprus (25 March 2013) came as a warning sign that further countries could still fall victim of the epidemic. It also exposed the fact that a consistent template for crisis response had

2. Troika in this context means the body formed by the European Commission, the IMF and the European Central Bank (ECB) to oversee the implementation of memoranda of understanding in Greece, but also subsequently in Ireland, Portugal and Cyprus. 
not been invented. In fact the impression was that, once the ECB creates stability for euro, politicians are tempted to experiment with new ideas, tools and solutions, with a strong focus on how to avoid costs for taxpayers in richer countries.

In 2013-2014, the EU was emerging from the crisis with a great delay as compared to the US. Although most euro area countries already experienced positive growth rates and falling unemployment, the 2014 European Parliament elections made it clear that citizens want to see more action for growth and job creation. The announcement of the European Investment Plan on 26 November 2014 was an answer to these calls from the newly established Juncker Commission. The need for a coordinated plan, with a central role for the European Investment Bank (EIB) also signalled that the private banking system was still unfit to finance a robust recovery. The strong focus on the Investment Plan, together with a new approach to the European Semester and the sequencing of the policy objectives in the Annual Growth Survey, signalled a new paradigm in which growth primarily comes from investment as opposed to frontloaded fiscal consolidation (austerity) or structural reforms.

Greece was first in and last out of the euro area debt crisis. The country had lost about a quarter of its GDP, and in 2015, despite an overall EU recovery, it was still facing the need for a third bail-out package with creditors, and demands for maintaining a primary budget surplus from them. Newly elected Prime Minister Alexis Tsipras organized a referendum (5 July 2015) about the conditions of this bail-out, and the majority of Greeks rejected further austerity. This created an awkward situation where people want to keep the single currency but reject the conditions of the loans that keep them afloat inside it. Greece was in fact offered an orchestrated exit from euro, but eventually it was not the preferred option, even though austerity was rejected by the people.

It can be debated whether the financial crisis has ended at all. Legacy debts, banking problems and unemployment look like staying for a long time. However, one particular moment stands out when the old approach to EMU economic governance spectacularly fell from grace. The decision of EU finance ministers to impose a zero euro fine ${ }^{3}$ on Spain and Portugal (9 August 2016) signalled that the fiscal rules in the Stability and Growth Pact (SGP) cannot be applied automatically; social and political aspects have to be considered. Fiscal rules looked dead until the next stand-off, this time between the Italian government and the rest of the EU, brought them back to life again.

It would be hard to draw one single conclusion out of this sequence of critical events (listed in Table 1). What these memorable moments definitely illustrate is that political considerations and human decisions of various types have been playing a major part in the crisis dynamics. Through better or worse decisions, government action has always been important in defining the course of the crisis and the recovery. It is remarkable, however, that EU governments have almost always been just too divided to arrive at decisive action in time. In fact it is the single currency itself which turned out to be more divisive than unifying, at least during the crisis period.

3. In August 2016, when Spain and Portugal were supposed to be fined under the SGP for violating deficit rules and not taking effective counter-action, the Commission eventually proposed a zero fine and the ECOFIN (European Council of Economic and Finance Ministers) acted accordingly. It was well understood by ministers that a mechanistic application of the rules and the imposition of punitive fines would have dealt a further blow to the credibility of EU economic governance after a period when several austerity-orientated governments had lost elections and the majority of the British people voted against continued EU membership. 
Table 1 Ten key moments of the great financial crisis in Europe

\begin{tabular}{|c|c|c|}
\hline Date & Event & Significance/lesson \\
\hline 2008 & $\begin{array}{l}\text { Lehman } \mathrm{Br} \\
\text { bankrup }\end{array}$ & $\begin{array}{l}\text { Failure to address systemic risk in world of } \\
\text { globalized finance; cycle is not dead }\end{array}$ \\
\hline November 2008 & $\begin{array}{l}\text { Hungarian loan } \\
\text { from IMF/EU }\end{array}$ & $\begin{array}{l}\text { Fragility of countries outside eurozone, } \\
\text { continuing importance of IMF }\end{array}$ \\
\hline May 2010 & 1st Greek bail-out & $\begin{array}{l}\text { Euro area requires common crisis response; } \\
\text { new instruments have to be created }\end{array}$ \\
\hline 19 October 2010 & Deauville $(M \& S)$ & $\begin{array}{l}\text { 'Extend and pretend' is wrong; bail-out by } \\
\text { taxpayers should not be only game in } \\
\text { town }\end{array}$ \\
\hline Decer & Italy pens & $\begin{array}{l}\text { Eurozone crisis management is in conflict } \\
\text { with national democratic and welfare } \\
\text { systems }\end{array}$ \\
\hline 26 July 2012 & $\begin{array}{l}\text { Draghi: whatever it } \\
\text { takes }\end{array}$ & $\begin{array}{l}\text { Austerity within countries does not lead to } \\
\text { recovery; eurozone needs lender of last } \\
\text { resort }\end{array}$ \\
\hline 25 March 2013 & Cyprus bail-in & $\begin{array}{l}\text { Once ECB creates stability for euro, politi- } \\
\text { cians are tempted to experiment }\end{array}$ \\
\hline 26 November 2014 & Juncker Plan & $\begin{array}{l}\text { Growth comes from investment; banking } \\
\text { system still unfit to finance recovery }\end{array}$ \\
\hline 5 July 2015 & Greek referendum & $\begin{array}{l}\text { Exit from euro is not preferred option, even } \\
\text { if austerity is rejected by people }\end{array}$ \\
\hline 9 August 2016 & $\begin{array}{l}\text { ECOFIN ES/PT } \\
\text { decision }\end{array}$ & $\begin{array}{l}\text { SGP rules cannot be applied automatically, } \\
\text { social and political aspects have to be } \\
\text { considered }\end{array}$ \\
\hline
\end{tabular}

Note ECOFIN = European Council of Economic and Finance Ministers; ES/PT = Spain/Portugal; SGP $=$ Stability and Growth Pact.

\section{THE EMU: FROM UNIFYING TO DIVISIVE}

The EU was designed with the goal in mind of overcoming the various forces of nationalism that had divided the continent for centuries. As a program for peace, it includes certain economic tools, one of which, over the last three decades, has been the single currency. The question, however, is how far the EMU can fulfil its unifying mission.

Based upon the experience of the recent crisis and subsequent reform period, we can examine the question of unity ${ }^{4}$ at four levels: the German-French axis, the North-South polarization, the UK and the Continent, and the East-West asymmetry.

Monetary integration in Europe, like economic integration in general, has always relied primarily upon Franco-German cooperation. In the 1970s, Valéry Giscard d'Estaing and Helmut Schmidt worked together to develop the European Monetary System (EMS), first as finance ministers, and then as President and Chancellor respectively. Another outstanding pair, Francois Mitterrand and Helmut Kohl, facilitated the 1992 Maastricht Treaty.

These leaders managed to overcome the intellectual divide described recently by Markus Brunnermeier, Jean-Pierre Landau and Harold James (2016): Germany considers the EMU to be primarily a rules-based stability union, while France considers growth and stability to be of equal importance, allowing for the use of common (and discretionary) policy instruments in the event of crisis.

4. For a longer elaboration on this topic, see Andor (2018). 
This basic divide reappears all the time, in different guises. Today, the whole world is watching whether a partnership comparable to earlier ones could at last emerge. Emmanuel Macron came as the fourth French counterpart of Angela Merkel and he has had only a brief window of opportunity to convince the German leadership about the importance of substantial change.

Franco-German understanding in the area of economic policy and more specifically eurozone reform has been cultivated by cooperation between two groups of economists: the so-called Eiffel Group ${ }^{5}$ and the Glienicker ${ }^{6}$ Group. Their very modest proposals appear to be too radical for making a more direct and substantial impact on decisionmaking in their respective countries and at EU level. In 2018, convergence between German and French views on the EMU took place not by Berlin becoming more ambitious but by Paris starting to scale down expectations.

France and Germany should not only speak to each other, but also to others in the EU, in particular the countries of Southern Europe. During the period of the so-called eurozone crisis (2011-2013), major divergences developed between the North and the South, or more precisely between the core and the periphery. Financial fragmentation and capital flight caused longer and deeper recessions on the periphery, which pushed unemployment up to record levels and increased poverty levels too. Political structures were shaken and a crisis of governability has been observed.

Since 2011, the break-up of the eurozone with the departure of one or several member states was an oft-discussed scenario, even if most did not regard it as desirable. Various anti-EU forces - the National Front (now renamed National Rally) in France and the Northern League in Italy, for instance - in certain periods raised EMU break-up as a possible solution, but in 2015 it was a very mainstream politician, the German finance minister, Wolfgang Schäuble, who offered Greece a 'five-year holiday' from the euro; the temporary nature of such a holiday was not taken seriously and it was seen as an invitation to exit not just for five years but permanently.

Beyond the polarization between North and South, one should also look at the role of the euro in the rise of British isolationism as well. The UK Independence Party (UKIP), a main driver of the 2016 June referendum, ${ }^{7}$ was formed at the time of the Maastricht Treaty and currently still uses the Sterling symbol in its emblem. The eurozone crisis gave a lot of ammunition to UK eurosceptics who wanted to prove that 'the EU is not working'. At the time of the 2014-2016 debates on EU membership, it was not so much the existence of the euro which fuelled UK euroscepticism but its functioning and performance. As pro-Brexit campaigners often said: Britain was chained to a corpse.

The eurozone crisis also boosted migrant flows from the South to the UK, making it harder to reduce the level of immigration as promised by the Conservative government of David Cameron, and many Britons became disaffected when they saw how the community (or, more precisely, the eurozone finance ministers) treated its most unfortunate member, Greece, in the summer of 2015 . Some people asked if this really was a community to which Britain should belong.

British people voting for Leave did so for a variety of reasons in June 2016. However, the project of monetary integration and the 30 -year debate around it repeatedly played a

5. See http://bruegel.org/author/the-eiffel-group/.

6. See http://bruegel.org/author/the-glienicker-group/.

7. The UK referendum on continued membership in the EU (Remain or Leave) was called by Prime Minister David Cameron who resigned after the narrow victory of those who wanted to exit the EU. 
role in putting a wedge between Great Britain and the Continent, eventually contributing to the vote to Leave.

Following a post-Brexit reflection, in September 2017, Commission President JeanClaude Juncker outlined his vision to reunite both the eurozone and the EU. As part of this, to ease the further enlargement eastwards of the eurozone, he proposed a budget line that would smooth entry for those who might wish to join in the coming period. This proposal revives the original idea that there should be no separation between the currency union and the single market.

However, some non-eurozone countries show absolutely no intention of accelerating the process of accession. When we look for the reasons for keeping a distance from the single currency in Poland, Hungary and Czechia within the Visegrad group, but also Sweden in the North, it is by and large an insistence upon policy-making autonomy and sovereignty.

The dilemma of joining the eurozone is thus essentially about the choice between sitting at the 'top table' but accepting more rule-taking and having elbow-room for more discretionary decisions with a modest risk of being sidelined occasionally. In the current political environment, marked by strong Polish, Czech and Hungarian nationalism, the power elites clearly favour more discretion and autonomy. But this also involves their taking on the risk of becoming part of a political periphery within an envisaged two-tier EU.

\section{TRIANGULAR DEBATE ON THE EMU}

It is not only countries but also experts who have been divided about the nature of the eurozone crisis and the way forward. In and after 2012, when the EMU reform began, the debate was binary. One would either defend the original Maastricht design or advocate a federalist-inspired reform. Austerity was linked to the first position and acceptance of a transfer union to the second. The first position has been advocated by economists like Hans-Werner Sinn, Otmar Issing and Jürgen Stark, the second by academic critics like Joseph Stiglitz (2017) and Paul Krugman in the US as well as Paul De Grauwe and Peter Bofinger in Europe. The first approach was clearly dominant in the early period of eurozone crisis response (2010-2011) but started to lose ground after the turn-around by the ECB and the proposed Banking Union.

Representatives of the second tendency not only criticized austerity but also outlined many concrete steps that would need to be taken to make the EMU resilient and sustainable in the long run. The usual 'shopping list' includes the completion of the Banking Union (with deposit insurance), the widening of the ECB's mandate (similar to that of the US Fed), the creation of safe assets, and the integration of the ESM into community law. Some form of unemployment insurance would also be justified and necessary.

In contemporary discussions, some would like to see faster progress, while others would prefer to take a few steps backward and withdraw tools established at the time of the crisis (for example, abolishing the ESM or streamlining the European Semester). The debate, therefore, is not only about speed, but also direction. Having witnessed the stalemate between fiscal federalists and ordoliberals, some have advocated for a third position which rejects both fiscal union and excessive austerity. It puts forward the 'renationalization' of fiscal rules and the restoration of the 'no bail-out' principle, together with the establishment of a sovereign default mechanism.

Under this 'third option', surplus countries would stop pushing for austerity and deficit countries would stop pushing for transfers. Risk-renationalization - not risk-sharing or risk-reduction - is the solution. Completing the Banking Union is desirable but efforts 
to move towards fiscal union are pointless for both economic and political reasons. Nor is there a need to monitor divergence in the eurozone or strengthen the social dimension of the EMU.

Leading economic theorists and commentators like Philippe Legrain (2014), Charles Wyplosz (2014), Martin Sandbu (2016) and Simon Wren-Lewis (2016) can be seen as representing the third option. Barry Eichengreen (2018), originally close to the systematic reform tendency, has also moved closer to this position. Their fundamental message is that for Europe's economic (and social) misfortunes not the euro but incompetent political leaders should be blamed.

In his book Sandbu argues that the allegedly incomplete nature of the EMU has never been a problem. Political leaders who before and during the crisis missed opportunities (for example, debt relief to Greece) or took necessary decisions with just too much delay (for example, quantitative easing) are at fault. Better decisions would have averted the 2011-2012 eurozone crisis (for example, counter-cyclical as opposed to pro-cyclical monetary policy in 2010-2011).

While there is no doubt about the need for good decisions, the question is whether the Union can rely on these in future without institutional guarantees (and even automaticity in certain aspects). Without those, individuals (current and future decision-makers) would need to go through a rapid learning process and become highly skilful at avoiding pitfalls during the next emergency. This also requires the capacity to reconcile national and European interests at a time of financial market turbulence, since many of the 'bad' decisions were not necessarily bad from a national point of view but became ineffective or counterproductive in an all-European perspective.

\section{SLOW-MOTION EMU REFORM}

We have seen that the functioning of the single currency in practice has been more divisive than unifying from the perspective of the EU as a whole. But divisions have always tended to block systemic reforms instead of spurring them. The only period when high-level agreement on reconstruction looked at all possible was when the single currency came close to disintegration.

Between 2010 and 2014, the EU went through a cataclysmic financial and economic crisis, which nearly destroyed the euro. The tide turned in 2012, when the ECB was authorized to intervene with an expanded toolkit to stem the financial panic, and reform of the EMU began with the announcement of the proposed Banking Union. In the same year, the Commission was also asked by the European Council to work on the EMU's social dimension.

Because of these changes, the eurozone has experienced a recovery in the last four years, when GDP growth has been positive and unemployment falling. In this more benign environment, however, reconstruction was seen as less urgent, as the more influential member states felt no need to move ahead with EMU reform. The new institutions that have been created in response to the crisis are not insignificant, but they need to be developed further, in terms both political legitimacy and systemic effectiveness.

For example, the European Stability Mechanism (ESM) was already proposed in 2010 and made permanent in 2012, when it was also rendered more substantial in volume. However, the ESM also awaits further reform steps, especially on how it should be integrated within communitarian structures.

Two pillars of the Banking Union were established by the Barroso II Commission by 2014, but no progress has since been made so deposit insurance has not been added to 
the regulatory and resolution functions. Thus, the Banking Union remains incomplete and fiscal risk-sharing has effectively been ignored. Instead, a capital-market union (CMU) has been promoted on the argument that, if risk-sharing is required inside the EMU, it needs to take place in the private sector and not through the channels of public finance.

Given the threat of disintegration in 2012, a number of EU documents confirmed the need for closer cooperation in the wake of the euro crisis. Together with the Four Presidents' Report, ${ }^{8}$ the Commission's Blueprint for a Deep and Genuine Monetary Union and the European Parliament's Thyssen Report ${ }^{9}$ on the Four Presidents' Report can be mentioned. These documents pointed towards fiscal union, banking union, and political union as well. However, the necessary consensus and high-level political commitment did not emerge; it proved easy to slow down the process of reform and divert it in all sorts of directions.

The Four Presidents' Report was followed up in 2015 by a Five Presidents' Report, ${ }^{10}$ which further elaborated on the problem of divergence and enhanced vital aspects of political legitimacy. At the same time, it stepped back from the vision of fiscal and political unions and spoke merely about fiscal capacity and stabilization functions in very vague terms. The high-quality reflection paper on the future of the EMU published by the Juncker Commission was followed in December 2017 by a Communication with modest proposals ${ }^{11}$ largely ignored by the European Council.

The European Union spent much of 2017 contemplating its future, publishing a 'white paper' on the 60th anniversary of the Treaty of Rome. This document outlined five possible future scenarios, supplemented by five additional 'reflection papers', on subjects including globalization, the social dimension, Economic and Monetary Union (EMU), and the finances of the EU. The idea was to shore up the EU's foundations and unify the member states behind a common vision, following the United Kingdom's decision to leave the bloc.

The unlikely volunteer who unexpectedly went further than the Commission's 2017 Communication is German Finance Minister Olaf Scholz, who in 2018 started to advocate a model of unemployment reinsurance based on loans to support national unemployment benefit schemes at times of major crises. Even in this mild form, the idea sounded radical for many, despite being present in reflections and analysis on monetary integration ever since the 1975 Marjolin Report. The European Council apparently closed this 'non-reform cycle' in December 2018, while Commission President Juncker also came forward as a supporter ${ }^{12}$ of the unemployment insurance idea as the new year began.

Since the 2011-2012 eurozone crisis, several EU documents have pointed to the need for a 'fiscal capacity' to stabilize the single currency and thus make it truly sustainable. Indeed, certain functions (cross-border risk-sharing and counter-cyclical stabilization)

8. Presidents of the European Council, European Commission, European Central Bank and the Eurogroup (Herman Van Rompuy, Jose Manuel Barroso, Mario Draghi and Jean-Claude Juncker). 9. See http://www.europarl.europa.eu/sides/getDoc.do?type=REPORT\&reference=A7-20120339\&language $=\mathrm{EN}$.

10. Adding Martin Schulz, President of the European Parliament.

11. The proposals were: establishing a European Monetary Fund; integrating the substance of the Treaty on Stability, Coordination and Governance into the Union's legal framework; establishing new budgetary tools for stabilization; as well as a Finance Minister for the euro (Watt 2017).

12. See 'Clarification regarding press reports on President Juncker comments on a European unemployment insurance', Commission press release, 5 January 2019 (http://europa.eu/rapid/ press-release_IP-19-141_en.htm). 
can be performed only via fiscal instruments in a monetary union. Following calls for a fiscal capacity, including from the European Parliament and the newly elected French President Emmanuel Macron, the Commission President in his 2017 State of the Union speech announced that a dedicated eurozone budget line would be embedded in the next Multiannual Financial Framework (MFF) (EU seven-year budget) proposal.

Although previously new requests and suggestions were linked to the eurozone as it now stands, this solution is consistent with the Treaty definition of the euro as the currency of the whole European Union. On the same basis, calls for a separate eurozone parliament have also been rejected, since it is the full European Parliament which is competent on all related matters. At the same time, the Commission voiced its intention to reunite the EU and the eurozone - a proposal that, post-Brexit, may face fewer hurdles, given that out of all eight non-eurozone countries only Denmark ${ }^{13}$ is under no obligation to introduce the single currency as soon as the criteria are met. Thus, the point is not so much that the proposed eurozone budget should be embedded within the MFF but what concrete tools are put forward and how they would work.

\section{EUROZONE FISCAL CAPACITY PROPOSAL WITHIN THE EU BUDGET}

In its proposal for a new MFF (2021-2027), the Commission included two new tools associated with the eurozone. These are: a Reform Support Program (RSP) with €25 billion for seven years, and a European Investment Stabilization Function (EISF) with €30 billion for the same period. The RSP, apart from offering a Reform Delivery Tool and technical assistance, also introduces a Convergence Facility to provide dedicated support for member states seeking to adopt the euro. But the precise goals and functions of these new instruments will determine whether they can at least be called 'steps in the right direction'.

Starting with the RSP, this is designed to support structural reforms within the member states in line with recommendations outlined in the European Semester. The benefit and function of such an instrument is not obvious for several reasons. First, a monetary union justifies fiscal tools that are more cyclical than structural. Events that trigger fiscal support require urgent treatment; they cannot wait for the next round of the Country Specific Recommendations (CSRs). On the other hand, the previous round of CSRs may not be relevant for the new situation, should a financial crisis occur in the autumn (which is normally the case). Second, a practical difficulty is: how should structural reforms be 'priced'? How could one design a menu with reforms and related financial envelopes that would, in an even-handed way, apply from Finland to Portugal, and from Ireland to Bulgaria? Even more importantly, the content of the support programs also has to be scrutinized. If such programs just serve the purpose of internal devaluation, this may prove more controversial and counter-productive than helpful.

Altogether, the RSP seems to revive an old (and failed) idea, which was on the table of the European Council in the 2012-2013 period: the Competitiveness and Convergence Instrument (CCI). It was shredded owing to much the same concerns as outlined above. The RSP appears to be at best an attempt at political fudge, promoted by those who fear

13. It is ironic that Denmark, which has the right to keep its national currency forever, is from an economic point of view closer to the eurozone than some other non-eurozone countries that maintain floating currencies and inflation targeting regimes, such as Sweden or Poland. 
that economically sounder instruments will be impossible to agree politically. A harsher assessment would be that the RSP is a hobbyhorse of people who forgot nothing but learned nothing from experiencing the crisis. A combination of a robust cohesion policy and new instruments for counter-cyclical stabilization would be a superior solution.

The second newly proposed tool, the EISF, is supposed to maintain the continuity of investment projects in times of crisis. However, it would not serve as a source of direct transfers but of loans, designed to offset any hike in interest rates in a turbulent period. This tool would indeed serve a useful purpose, but at this stage there are still question marks around it. In a major crisis, it is not unnatural to reprogram investment projects, and this process might well be lengthy. This may also cause delay in the arrival of support from the EU institutions. Besides, the crisis also means that some economic actors may have changed significantly or even disappeared from the stage in the meantime, which causes further complications.

Crucially, any support from this facility would be destined for a specific project, which probably means that the effect would be local, or at least territorially concentrated. The EISF might then provide uneven support in times of asymmetric shocks, leaving large parts of a country and its population uncovered. One way to mitigate this risk would be to modulate the EISF so as to include general budget support that may also be used to co-finance country-wide social investments, for example teachers' salaries.

If we consider the speed of intervention and the targeted nature of support, investment stabilization remains a poor substitute for unemployment insurance. Regarding the latter, various models have been put forward in recent years, including partial pooling of unemployment benefit schemes (Dullien 2014) or the reinsurance of national unemployment funds (Gros et al. 2015). Had either of these insurance mechanisms existed from the start of the single currency, all member states would have been beneficiaries for a shorter or longer period. Countries experiencing a severe recession would have received temporary fiscal transfers, helping them towards a faster recovery and avoiding a perception that for the EU arbitrary fiscal targets are more important than democracy and social cohesion.

After the Commission unveiled its own favoured fiscal tools to be integrated into the new MFF, the small scale and bogus nature of these instruments led Financial Times columnist Wolfgang Münchau to call the approach homeopathic. On the other hand, discussion of these token instruments allows for a new round of debate about effective stabilization in the eurozone. There are multiple options to resolve this problem. One may opt for a new stabilization facility comparable in size to the existing EU budget, or a significant relaxation of the fiscal rules. Further innovative action inside the ECB, however opaque, is also possible. One of these directions, however, has to be chosen before it is too late. Budgetary solutions have the advantage of being rules-based, targeted and transparent, and of involving political accountability, as long as they are appropriately designed.

The small size of the proposed budget makes it necessary to explore whether the revenue side can also help in the stabilization function by bringing in new incentives with a rebalancing effect. For example, it would be logical to impose a small levy on currentaccount surpluses. The EU has named excessive current-account surpluses as destabilizing factors since 2010, under the Macroeconomic Imbalances Procedure (MIP), but no sanctions were attached, and moral suasion alone has proven ineffective. The new MFF provides an opportunity to put into real effect the rule that requires surplus countries (Germany and the Netherlands most of all) to increase domestic investment and wages and thus boost aggregate demand, helping themselves but also the whole community at the same time. 


\section{CONCLUDING REMARKS}

Establishing a currency union has been a symbol and driver of an ever-closer union. However, in its original design, the single currency has also contributed to current cleavages and asymmetries. North-South divergence was particularly serious at the time of the 2011-2013 eurozone crisis, which helped to drive the UK out of the EU and made some non-eurozone countries more cautious about accession.

Without substantial eurozone reform it is hard to see how the unifying role of the single currency could be strengthened and the gap between the EU and the eurozone closed. To avert an eventual break-up, convergence has to be restored. And to regenerate convergence, the system needs to be corrected and, for lasting convergence, fundamental reform is needed.

Slogans like 'Europe is back on track' may have been in circulation in 2018, but in the absence of reinforced instruments we might just be sleepwalking into the next crisis. The incapacity of political leaders in surplus countries to explain these risks to their public (together with the necessity of fiscal risk-sharing) has been a major barrier to progress in recent years.

If and when eurozone reform can be relaunched, the most urgent task will be the completion of the Banking Union by adding deposit insurance (EDIS) to the existing pillars, and the introduction of fiscal stabilizers in support of risk-sharing and convergence. Such measures do not require a federal leap or treaty change. Political leaders must convince the public of the necessity of repairing the EMU and preparing it for the next downturn by adding effective shock-absorption tools.

There have been many signs that the old order has been dying but not 'yielding place to the new'. Following the Four Presidents' Report in 2012 and the Five Presidents' Report in 2015, a Six Presidents' Report could have been produced in 2018 to maintain the rhythm of reform cycles. One may wonder how many EU Presidents it takes to draft a report which truly convinces national leaders but also the general public about the need for a robust EMU reform process.

Despite multiple calls for 'repairing the roof while the sun shines', the EU seems to be approaching the next economic downturn without a sufficiently reformed and reinforced monetary union. One may be left with the impression that the EU is not reforming either when the sun is shining or when it is raining, only when the sky is falling. And it surely will ...

\section{REFERENCES}

Andor, L. (2018): The unifying role of the single currency, in: Intereconomics, 53(4), 215-220.

Brunnermeier, M.K., Landau, J.P., James, H. (2016): The Euro and the Battle of Ideas, Princeton, NJ: Princeton University Press.

Dullien, S. (2014): A European Unemployment Benefit Scheme: How to Provide for More Stability in the Euro Zone, Gütersloh: Bertelsmann Stiftung.

Eichengreen, B. (2018): The euro at 20: an enduring success but a fundamental failure, in: The Conversation, 4 January, URL: https://theconversation.com/the-euro-at-20-an-enduring-success-buta-fundamental-failure-108149.

Gros, D., Beblavy, M., Maselli, I. (2015): Reinsurance of national unemployment benefit schemes, Policy Contribution, CEPS, URL: https:/www.ceps.eu/ceps-publications/reinsurance-nationalunemployment-benefit-schemes/.

Legrain, P. (2014): European Spring: Why Our Economies and Politics are in a Mess - and How to Put Them Right, London: CB Creative Books.

Sandbu, M. (2016): Europe's Orphan: The Future of the Euro and the Politics of Debt, Princeton, NJ: Princeton University Press. 
Stiglitz, J.E. (2017): The Euro: How a Common Currency Threatens the Future of Europe, New York: W.W. Norton.

Watt, A. (2017): Deepening EMU: commission makes limited steps (mostly) forward, $€$-Vision blog, 6 December, URL: http://andrewwatt.eu/2017/12/06/deepening-emu-commissionmakes-limited-steps-mostly-forward/.

Wren-Lewis, S. (2016): The eurozone's flaws are not intrinsic, in: Intereconomics, 51(1), 20-24.

Wyplosz, C. (2014): The eurozone crisis: a near-perfect case of mismanagement, in: Economia Marche Journal of Applied Economics, XXXIII(1), 1-13.

\section{FURTHER READING}

Bibow, J. (2018): Twenty years of the German euro are more than enough, The Levy Economics Institute Working Paper Collection No 911.

Mody, A. (2018): EuroTragedy: A Drama in Nine Acts, Oxford: Oxford University Press.

Pisani-Ferry, J. (2018): Euro area reform: an anatomy of the debate, Vox - CEPR Policy Portal, 2 October. 